\title{
MICROCOCCUS TETRAGENUS INFECTION
}

\author{
I. Review of the Literature, Report of a Non-fatal Case with Septicemia, \\ Meningitis and Arthritis, and Bacteriologic Studies \\ By HOBART A. REIMANN \\ (From Department of Medicine, University of Minnesota Hospital, Minneapolis)
}

(Received for publication November 28, 1934)

The appearance of only two or three reports (Greiwe, et al. (1), Steele (1)) of Micrococcus tetragenus infection in American medical literature would lead one to believe the disease to be rare and of little importance. It is probably quite common, but often disregarded or unrecognized in this country. More than 170 cases have been reported in Italian, French, German, English and Spanish journals.

Micrococcus tetragenus, after its discovery in 1881 by Koch and Gaffky, was believed to be a harmless saprophyte residing in the normal nasopharynx and often in tuberculous cavities in the lung. Its pathogenicity was first recorded by Jakowski (2) in 1886. Later Mya and Trambusti (3) reported two cases of septicemia, and Viquerat (4) produced suppuration by injecting cultures of $M$. tetragenus into blister sacs on tuberculous patients. The organism is, however, of comparatively low virulence and becomes invasive only under certain conditions in which the resistance of the host is reduced. When infection does occur, it resembles the local suppuration or septicemia with metastatic localization due to the closely related staphylococcus. The organism appears to have a predilection for serous membranes, but also invades parenchymatous organs.

All of the published reports, except two, deal with sporadic cases. Two small epidemics have been reported among soldiers during the World War; one by Birks, Thornley and Fawcus (5) who observed 25 cases of septicemia, and one by Trémolières and Loew (5) with 45 cases. In both series the mortality rate was low and the general features illustrated the importance of predisposing factors. In many of the cases, $M$. tetragenus was probably a secondary invader.

Clinically, the infection is characterized by features common to pyogenic infections due to other cocci. The case reported here conforms to the prototype of the usual course. A brief summary of certain salient features of the disease, taken from reports giving adequate data in available journals, is given in Table I. Many French and Italian articles (6) are short and devoid of details.

The infection is apparently commonest in young adults. The onset is usually abrupt and is almost invariably preceded by some predisposing cause which presumably lowers resistance and makes invasion possible. Sore throat and respiratory tract infections are the commonest, as would be expected, since $M$. tetragenus often resides in the normal nasopharynx. Other predisposing factors are anemia (Mya and Trambusti (3), Arullani (7), Brugnola (1)), abscesses (Jakowski (2), Viquerat (4), Achard and Gaillard (8), Steele (1) and others) and urinary tract infections (Gayet (9) and others). Interesting cases have been observed both preceding and following typhoid fever (Anglada (7), Laignel-Lavastine and Baufle and Meltzer (1)), several accompanying septicemia due to streptococci (Meltzer (1)) and one with brucelliasis (10). The course of the infection may be mild or severe and is characterized by chills, sweats, remittent fever, moderate leukocytosis and often by splenomegaly. Fulminating cases have ended fatally on the seventh day (Leschke (1)), and protracted cases may last 7 months (Castaigne (1)). The mortality rate judged from 44 cases of septicemia in which the outcome is stated is 50 per cent.

Reports of more than 127 cases of septicemia are available, many of which also show localization in various parts of the body. Cases with septicemia alone are referred to in Table I and are reported in the papers of Mya and Trambusti (3), Arullani, Boni, Anglada, Tillaye, Marcora 
TABLE I

Summary from literature of features of Micrococcus tetragenus infection

\begin{tabular}{|c|c|c|c|c|c|c|c|c|c|c|c|}
\hline & Sex & Age & $\begin{array}{c}\text { Predisposing } \\
\text { factor }\end{array}$ & Onset & Dura- & Outcome & $\begin{array}{l}\text { Septi- } \\
\text { cemia }\end{array}$ & Arthritis & $\begin{array}{l}\text { Menin- } \\
\text { gitis }\end{array}$ & $\begin{array}{c}\text { Other } \\
\text { localization }\end{array}$ & $\begin{array}{c}\text { Other } \\
\text { observations }\end{array}$ \\
\hline \multicolumn{12}{|c|}{ Cases with arthritis } \\
\hline $\begin{array}{l}\text { Chaufiard, A., and } \\
\text { Ramond, F.,Arch. } \\
\text { de méd. Exper., } \\
1896,8,304\end{array}$ & $\mathbf{M}$ & $\begin{array}{c}y r s . \\
15 \\
18\end{array}$ & Influenza & $\begin{array}{l}\text { Gradual } \\
\text { Sudden }\end{array}$ & $\begin{array}{l}11 \text { days } \\
10 \text { days }\end{array}$ & $\begin{array}{l}\text { Fatal } \\
\text { Fatal }\end{array}$ & + & + & & $\begin{array}{l}\text { Endocardi- } \\
\text { tis }\end{array}$ & $\begin{array}{l}\text { Exanthem } \\
\text { Bronchitis, empy- } \\
\text { ema }\end{array}$ \\
\hline $\begin{array}{l}\text { Bertaux, A., cited } \\
\text { by Lartigau (13) }\end{array}$ & $\mathbf{M}$ & 37 & Sore throat & & & Recovered & + & + & & $\begin{array}{c}\text { Pneumonia, } \\
\text { phlebitis }\end{array}$ & \\
\hline $\begin{array}{l}\text { Faisans and Le Da- } \\
\text { many, Semana } \\
\text { med., 1897, 17, } \\
258\end{array}$ & & & Sore throat & & & Fatal & & + & & $\begin{array}{l}\text { Pneumonia, } \\
\text { empyema, } \\
\text { exanthem }\end{array}$ & \\
\hline $\begin{array}{l}\text { von Ofenheim, E., } \\
\text { Proc. Roy. Soc. } \\
\text { Med., Clin.Sect., } \\
\text { 1909, 2, 164 }\end{array}$ & M. & 38 & Abscess & Gradual & 5 months & Recovered & + & + & & Exanthem & $\begin{array}{l}\text { Typhoid fever and } \\
\text { rheumatic fever } \\
\text { first considered. } \\
\text { No specific agglu- } \\
\text { tinins; treated } \\
\text { with vaccine }\end{array}$ \\
\hline $\begin{array}{l}\text { Stroebel, Beitr. z. } \\
\text { klin. Chir., 1913, } \\
\text { 83, } 718\end{array}$ & $\mathbf{M}$. & 26 & Thoracotomy & Sudden & & Recovered & + & + & & & \\
\hline $\begin{array}{l}\text { Leschke, E., Spez. } \\
\text { Path. u. Therap. } \\
\text { Kraus, Brugsch., } \\
\text { 1919, 2, 1103 }\end{array}$ & $\mathbf{M}$. & 23 & Sore throat & Sudden & 7 days & Fatal & + & + & + & & \\
\hline This report & $\mathbf{M}$ & 46 & Sore throat & Sudden & 7 weeks & Recovered & + & + & + & Prostate & $\begin{array}{l}\text { Rheumatic fever } \\
\text { and gonorrheal } \\
\text { arthritis first con- } \\
\text { sidered. No ag- } \\
\text { glutinins. Skin } \\
\text { test negative }\end{array}$ \\
\hline
\end{tabular}

Cases with pneumonia or empyema

\begin{tabular}{|c|c|c|c|c|c|c|c|c|c|}
\hline $\begin{array}{l}\text { Castaigne, J., Bull. } \\
\text { Soc. Anat., 1897, } \\
\text { 11, } 394\end{array}$ & F. & & Fractured leg & Gradual & 7 months & Fatal & + & $\begin{array}{l}\text { Spleen and } \\
\text { kidney ab- } \\
\text { scess }\end{array}$ & \\
\hline $\begin{array}{l}\text { Bosc, F. J., and } \\
\text { Galavielle, L., } \\
\text { Arch. de méd. } \\
\text { Exper., 1899, 11, } \\
70\end{array}$ & M. & 45 & & & & Fatal & & & \\
\hline $\begin{array}{l}\text { Bosc, F. J., Arch. } \\
\text { de méd. Exper., } \\
1900,12,159\end{array}$ & M. & 21 & $\begin{array}{l}\text { Long illness, } \\
\text { anemia }\end{array}$ & Sudden & & Fatal & + & $\begin{array}{l}\text { Peritonitis, } \\
\text { entero- } \\
\text { colitis }\end{array}$ & \\
\hline $\begin{array}{l}\text { Byers, J., and Hous- } \\
\text { ton, T., Lancet, } \\
1913,1,1723\end{array}$ & $\mathbf{M}$. & 11 & A "cold" & Sudden & & & + & Exanthem & \\
\hline
\end{tabular}

Cases with meningitis

\begin{tabular}{|c|c|c|c|c|c|c|c|c|c|}
\hline $\begin{array}{l}\text { Bezancon, F., and } \\
\text { Lepage, Semana } \\
\text { med., 1898, 18, } 40\end{array}$ & F. & 32 & $\begin{array}{l}\text { Following } \\
\text { childbirth }\end{array}$ & & & Fatal & + & + & \\
\hline $\begin{array}{l}\text { Greiwe, J. W., Fack- } \\
\text { ler, G. A., and } \\
\text { Mitchell, E. W., } \\
\text { Phila. Month. } \\
\text { Med. J., 1899, 1, } \\
\text { 528 }\end{array}$ & M. & 35 & & Sudden & 3 weeks & Fatal & & + & \\
\hline 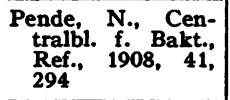 & F. & 48 & Previously well & Sudden & 5 weeks & Fatal & & + & \\
\hline $\begin{array}{l}\text { Bonanno, A. M., } \\
\text { Riforma med., } \\
1931,47,363\end{array}$ & M. & 28 & & Sudden & 4 weeks & Recovered & None & + & $\begin{array}{l}\text { Believed at first to } \\
\text { be brucelliasis }\end{array}$ \\
\hline
\end{tabular}


TABLE I (continued)

\begin{tabular}{|c|c|c|c|c|c|c|c|c|c|c|c|}
\hline & Sex & Age & $\begin{array}{l}\text { Predisposing } \\
\text { factor }\end{array}$ & Onset & $\begin{array}{l}\text { Dura- } \\
\text { tion }\end{array}$ & Outcome & $\begin{array}{l}\text { Septi- } \\
\text { cemia }\end{array}$ & Arthritis & $\underset{\text { gitis }}{\text { Menin- }}$ & $\begin{array}{c}\text { Other } \\
\text { localization }\end{array}$ & $\begin{array}{c}\text { Other } \\
\text { observations }\end{array}$ \\
\hline \multicolumn{12}{|c|}{ Cases with septicemia with miscellaneous localization } \\
\hline $\begin{array}{l}\text { Luigi, Fornaca, Ri- } \\
\text { forma med., 1903, } \\
19,309 \text { and } 346\end{array}$ & M. & $\begin{array}{c}\text { yrs. } \\
45\end{array}$ & & Sudden & 6 months & Recovered & + & & & Empyema & \\
\hline $\begin{array}{l}\text { Debove, Presse } \\
\text { méd., } 1907,15,41\end{array}$ & F. & 33 & $\overline{\text { Old endocarditis }}$ & $\overline{\text { Gradual }}$ & Months & Fatal & + & & & $\begin{array}{c}\text { Acute endo- } \\
\text { carditis }\end{array}$ & \\
\hline $\begin{array}{l}\text { Ziegler, } K \text {., Mún- } \\
\text { chen med. Wchn- } \\
\text { schr., 1908, 55, } \\
2487\end{array}$ & F. & $\overline{17}$ & Sore throat & Sudden & & Recovered & + & & & & \\
\hline $\begin{array}{l}\text { Caldera, } \mathrm{C}_{\text {., and } \mathrm{Pi}} \\
\text { naroli, G., Arch. } \\
\text { ital.di otol., 1911, } \\
\text { 22, } 34\end{array}$ & M. & 16 & $\begin{array}{l}\text { Chronic mas- } \\
\text { toiditis }\end{array}$ & Sudden & & Fatal & + & & & $\begin{array}{l}\text { Empyema, } \\
\text { lung gan: } \\
\text { grene }\end{array}$ & \\
\hline $\begin{array}{l}\text { Steele, A. E., } \\
\text { J.A.M.A., 1914, } \\
\text { 62, } 930\end{array}$ & $\overline{\mathbf{M}}$. & 24 & & & $\begin{array}{c}14 \\
\text { weeks }\end{array}$ & Fatal & + & . & & $\begin{array}{c}\text { Tibial } \\
\text { abscess }\end{array}$ & \\
\hline $\begin{array}{l}\text { Lüdke, H., München } \\
\text { med. Wchnschr., } \\
1920,67,454 \\
\end{array}$ & $\begin{array}{l}\mathbf{M} . \\
\mathbf{M}\end{array}$ & $\begin{array}{l}21 \\
34 \\
41 \\
\end{array}$ & \begin{tabular}{|l|} 
Sore throat \\
Typhoid fever \\
Sore throat
\end{tabular} & $\begin{array}{l}\text { Gradual } \\
\text { Sudden }\end{array}$ & 17 days & $\begin{array}{l}\text { Recovered } \\
\text { Recovered } \\
\text { Recovered } \\
\end{array}$ & + & & & Petechia & $\begin{array}{l}\text { Given specific vac- } \\
\text { cine }\end{array}$ \\
\hline $\begin{array}{l}\text { Kramar, E., Arch. } \\
\text { f. Kinderh., 1930, } \\
92,248\end{array}$ & & $\begin{array}{c}31 \\
\text { mos. }\end{array}$ & & & 3 months & Recovered & + & & & & $\begin{array}{c}\text { Specific agglutinins } \\
\text { in serum, } 1-640\end{array}$ \\
\hline $\begin{array}{l}\text { Looten, J., and Oui, } \\
\text { Ann. d. Gynec., } \\
\text { 1909, 6, 134 }\end{array}$ & F. & 24 & Difficult labor & Gradual & 6 weeks & Recovered & + & Arthralgia & & & $\overline{\text { Puerperal infection }}$ \\
\hline
\end{tabular}

(7), Ceraulo-Vetrano (10), Trémolières, Birks (5), Gayet (9) and others. Cases with localization in various parts of the body other than those listed in Table I are mentioned by the following authors: arthritis by Oettinger, Roger and Trémolières (11); meningitis by Vincent (12), Oettinger (11), Ramond (16), Rosenthal, von Riemsdk and Blum (12); respiratory tract lesions including mouth infections, pharyngitis, otitis media, bronchitis, pneumonia and empyema by Apert, Lewy, Lartigau, Park, Karlinsky, Steinhaus, Kapper, Netter, Delearde (13), Trémolières (5) and Kimmerle (14); endocarditis by Sterling (15), Gaucher, Perfetti (16), Lenhartz, Meyer (17) and pericarditis by Benoit (13) ; puerperal infection by Cathala and Guéniot (18), Bondy, Hüssy, Wegelius (7); peritonitis by Pane (3) and Müller (19); perinephritic abscess by Vease (16); and pyosalpinx by Wollgreen (7). Battistini (1) reported glomerulonephritis during septicemia and cultivated $M$. tetragenus from the patient's urine. Exanthemata have been noted by Chauffard and Ramond, Faisans and Le Damany, Adel, von Ofenheim, Byers and Houston, Lüdke and Stroebel (1). Gaucher (16) noted purpura. 
Only a few immunologic studies on patients have been made. Specific agglutinins were found in the serum by Meltzer, Brugnola (1) Trémolières (5) and Kramár (1) ; von Ofenheim and Debove (1) were unable to demonstrate significant titers. Several authors report beneficial effects from vaccine therapy (Lüdke, Battistini (1), Gayet (9)), others were unsuccessful (von Ofenheim (1)). Vaccine therapy in experimental animals was ineffectual (Lambea (20)).

Diagnosis.-Since the infection follows other diseases, as it often does, it is difficult to recognize for there are no pathognostic features aside from those common to other pyogenic infections. It has been confused with rheumatic fever, gonorrheal arthritis, tuberculosis, typhoid fever, malaria and sepsis due to other pyogenic cocci, especially the staphylococcus. At present, etiologic diagnosis can only be made by the isolation and identification of $M$. tetragenus from the blood or from other foci of infection.

\section{CASE REPORT}

On June 14 and 15, G. J., a fisherman, aged 46, drank alcoholic liquor excessively and awoke on the morning of the sixteenth feeling ill with a severe sore throat, headache, and alternating chilliness and sweating. He went to work, but soon became worse and retired because of knee was slightly swollen and painful. The overlying skin was neither reddened nor hot. The heart and lungs were normal. The prostate was tender but not enlarged and several drops of viscid white pus were expressed from the urethra on two occasions. No abnormal neurologic signs were noted. The clinical impression was acute rheumatic fever or gonorrheal arthritis.

Course. The arthralgia and fever were uninfluenced by amidopyrine. On June 27 , the tenth day of illness, the right knee became larger and $40 \mathrm{cc}$. of mucinous, lemon yellow, turbid pus was aspirated. The right wrist was aspirated but no pus was obtained. The knee was aspirated again on the eighteenth and twenty-second days; $60 \mathrm{cc}$. and $9 \mathrm{cc}$. of pus were removed. The patient's condition improved somewhat until the fifteenth day when generalized muscular twitching, irrationality, somnolence and pupillary inequality appeared. His neck was held rigid, the deep reflexes were hyperactive, but Babinsky's sign was normal. Lumbar puncture revealed cloudy fluid under $18 \mathrm{~mm}$. mercury pressure; $8 \mathrm{cc}$. were withdrawn. Spinal drainage was repeated at intervals 10 or 12 times thereafter. The patient voided involuntarily and the stools were diarrhoeal for a day.

Irrationality and somnolence persisted with brief, apparently lucid intervals. On the seventeenth day he complained of severe pain in the left shoulder. His neck was rigid and nystagmus was noted. He appeared to be moribund on the eighteenth day, but thereafter gradually improved. On the twenty-fourth day two shaking chills occurred. At times he was irrational, but the temperature gradually declined and remained normal after the

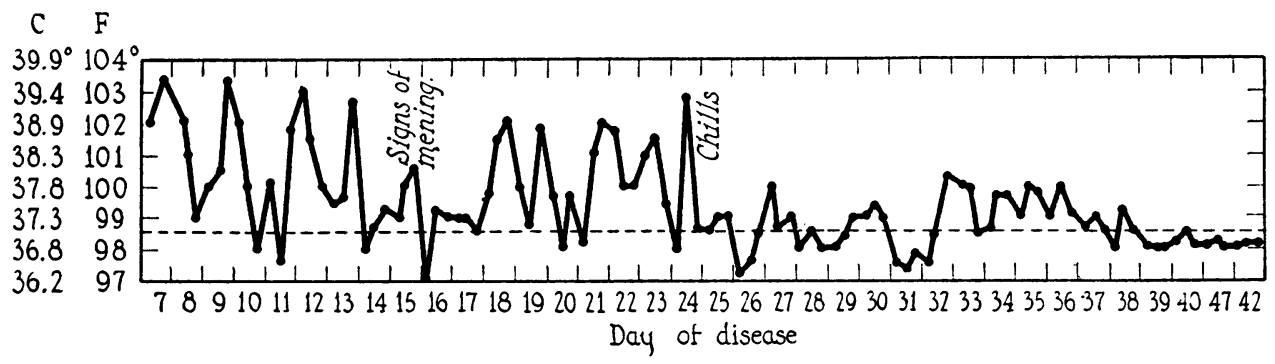

Fig. 1. Temperature Chart of Patient with $M$. tetragenus Septicemia, Arthritis and Meningitis.

backache and pain in his limbs. Headache was severe and constant. There was transient earache and partial deafness. After a day or two, pain localized in the right knee, shoulder and arm. On several occasions thereafter the backs of both hands became temporarily swollen and painful. His condition remained unchanged until he entered the hospital on the seventh day of illness. His past history was irrelevant except for gonorrhea in 1931.

Physical examination revealed a moderately ill, febrile patient evidently suffering from pain in his knee and shoulder. The pharyngitis had disappeared. There was tenderness and swelling of the right wrist, upper arm and shoulder, tenderness in the left shoulder, and the right thirty-eighth day. The fever was remittent and irregular as shown in Figure 1 . The pulse rate varied between 70 and 110.

Laboratory observations. There was slight albuminuria. The leukocytes ranged between 12,000 and 18,000 per cu. mm. The red cell count and hemoglobin were unchanged. The blood Wassermann was negative. The spinal fluid in the early period contained between 1400 and 3400 cells, mostly polymorphonuclear neutrophils, between 8 and $40 \mathrm{mgm}$. sugar, and the Pandy and Nonne tests were positive. The cell count gradually diminished to 21 on the sixty-fourth day when the last fluid was withdrawn at which time $55 \mathrm{mgm}$. of sugar were present. 


\section{BACTERIOLOGIC STUDIES}

Blood cultures. A blood culture in broth made on the ninth day showed gram-positive, irregularly shaped cocci in small clusters and a few in diploform after 24 hours at $37^{\circ} \mathrm{C}$. When subcultured on blood agar, a few minute colonies of small gram-positive cocci which were thought to be staphylococci grew in 24 hours. They were believed to be secondary invaders or contaminants and were not studied further. Subsequent blood cultures in broth made on the sixteenth and nineteenth days were sterile, but on one agar pourplate two whitish colonies appeared after 3 days. The colonies after a week at $37^{\circ} \mathrm{C}$. became yellow. The cocci composing each of these colonies were of two distinct kinds, large and small, and both occurred in tetrad formation (Figure 2A).

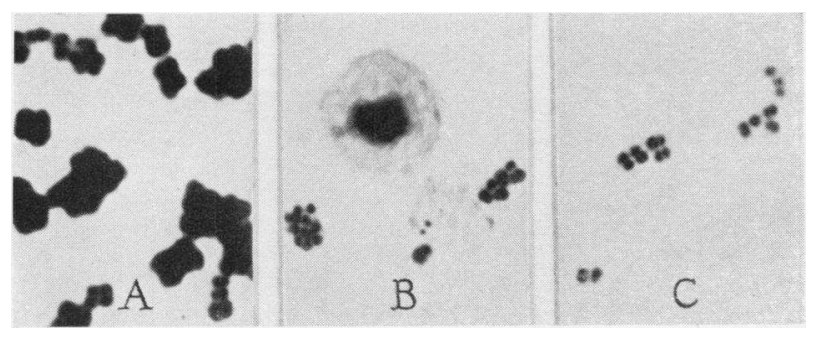

Fig. 2( $A)$. Large and Small Tetrads Composing a Yellow Colony Obtained from a Blood Culture on the Sixteenth Day of Illness. (B) Clusters of Pleomorphic Cocci Surrounded by a Halo (Capsule?) in Pus from the Knee Aspirated on the Tenth Day. (C) Small Diplococci and Tetrads (Capsulated?) Obtained from Broth Culture of Spinal Fluid on the Fiftefnth Day of Illness.

All magnified $\times 1150$.

Pus from the knee. In a smear made from pus aspirated on the tenth day, 3 clusters of grampositive, pleomorphic cocci were found after prolonged search (Figure 2B). One or two of the larger cocci were divided by a transverse fissure. The clusters appeared to be enclosed in a faintly staining pink capsule-like material. On a bloodagar plate inoculated with pus, one small whitish colony appeared composed of gram-positive cocci mostly in tetrad formation. Similar colonies appeared on plates streaked with pus removed on the eighteenth day. Cultures made from pus aspirated later were sterile.

Spinal fluid. Spinal fluid obtained on the fifteenth day was inoculated into 3 plain-broth tubes and on blood-agar plates. After 5 days incubation a slight stringy growth appeared at the bottom of 2 tubes. Smears from these cultures showed a few partly decolorized and some entirely gram-negative cocci, irregular in shape and size, mostly in tetrad formation. On subculture from one tube on a blood-agar plate, 14 small white colonies appeared after 18 hours, composed of gram-positive small tetrads. A halo surrounded the tetrads (Figure $2 \mathrm{C}$ ) which suggested a capsule, but none was stained nor demonstrable with India ink. Organisms from this colony were subcultured on blood-agar plates. After 48 hours, large greenish colonies surrounded by a green zone appeared. On several other bloodagar plates, hemolysis was noted where the colonies were crowded. On subculture on bloodagar or in blood-broth tubes hemolysis failed to recur. The colonies were composed of typical gram-positive tetrads. Similar results were obtained from cultures of spinal fluid obtained on the eighteenth day. At this time, one large white colony appeared on a plain-agar plate after 48 hours at $37^{\circ} \mathrm{C}$. After centrifugation of a sample removed on the twenty-seventh day, a few diplococci were seen for the first time in a direct smear. Thereafter, similar organisms were cultivated from each of the subsequent samples of spinal fluid by Dr. R. Koucky. The last culture was obtained on August 20, three weeks after the patient had become clinically well.

Urethral pus. Pus expressed from the urethra on two occasions showed a great predominance of gram-positive cocci, arranged singly, in pairs, in threes and many in tetrads and small clusters. Cultures on plain-agar after 24 hours at $37^{\circ} \mathrm{C}$. formed a heavy growth chiefly of whitish colonies composed of large gram-positive tetrads.

Rabbits, guinea pigs and white mice inoculated intraperitoneally with whole blood, spinal fluid, pus from the knee and with subcultures of the organism isolated from the three sources all survived. No agglutinins for the organism or any of its variant forms appeared in the patient's blood obtained at 5 intervals during and after his illness. A dilute suspension of cocci killed by heat at $60^{\circ} \mathrm{C}$. for $1 / 2$ hour and injected intracutaneously in the patient failed to cause erythema. The general characteristics of the iso- 
TABLE II

Cultural characteristics of $M$. tetragenus according to several authorities compared with the strain isolated from the case reported

\begin{tabular}{|c|c|c|c|c|c|c|c|c|c|c|c|c|}
\hline \multirow[b]{2}{*}{ Author } & \multirow[b]{2}{*}{ Form } & \multirow[b]{2}{*}{ Colonies on agar } & \multirow[b]{2}{*}{ Growth in broth } & \multirow[b]{2}{*}{ 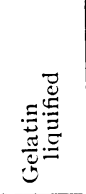 } & \multicolumn{5}{|c|}{ Acid in } & \multirow[b]{2}{*}{ 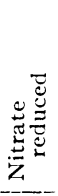 } & \multirow[b]{2}{*}{$\frac{n}{\infty}$} & \multirow[b]{2}{*}{ 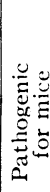 } \\
\hline & & & & & 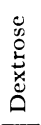 & $\begin{array}{l}0 \\
0 \\
0 \\
0 \\
0 \\
0 \\
\end{array}$ & 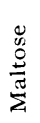 & 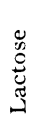 & $\stackrel{y}{\underline{3}}$ & & & \\
\hline $\begin{array}{l}\text { Sterling, S., Centralbl. f. } \\
\text { Bakt., } 1896,19,141\end{array}$ & $\begin{array}{l}\text { Capsulated tetrads in } \\
\text { blood culture }\end{array}$ & Yellow, round & & + & & & & & 0 & & & \\
\hline Leschke, E. (1) & $\begin{array}{l}\text { Tetrads, capsule present } \\
\text { in vivo and on solid } \\
\text { media }\end{array}$ & $\begin{array}{l}\text { Greyish-white, slimy. } \\
\text { Zone of hemolysis } \\
\text { on blood-agar }\end{array}$ & & 0 & & & & & & & + & + \\
\hline $\begin{array}{l}\text { Bergey, D. H., Manual of } \\
\text { Determinative Bacteri- } \\
\text { ology, Williams and } \\
\text { Wilkins Co., Baltimore, } \\
1925, \text { 2nd ed. }\end{array}$ & $\begin{array}{l}\text { Tetrads in vivo, pairs or } \\
\text { irregular masses in me- } \\
\text { dia, pseudocapsule }\end{array}$ & $\begin{array}{l}\text { White, smooth, glis- } \\
\text { tening }\end{array}$ & Clear, gray sediment & 0 & $\mathrm{~A}$ & & & $A$ & $A \pm$ & 0 & & + \\
\hline $\begin{array}{l}\text { System of Bacteriology, } \\
\text { Med. Res. Council, } \\
\text { London, } 1929,2,26\end{array}$ & $\begin{array}{l}\text { Large capsulated tetrads } \\
\text { in vivo; smaller and } \\
\text { single or pairs or groups } \\
\text { on media }\end{array}$ & $\begin{array}{l}\text { Surrounded by green } \\
\text { area on blood-agar }\end{array}$ & $\begin{array}{l}\text { Clouding first then } \\
\text { a deposit }\end{array}$ & 0 & & & aria & & & & & + \\
\hline $\begin{array}{l}\text { Principles of Bacteriology } \\
\text { and Immunology. Top- } \\
\text { ley, W. W. C., and Wil- } \\
\text { son, G.S., Arnold, Lon- } \\
\text { don, } 1929,1,393\end{array}$ & Capsulated tetrads & $\begin{array}{l}\text { Glutinous, difficult } \\
\text { to emulsify }\end{array}$ & $\begin{array}{l}\text { Thick, weedy gluti- } \\
\text { nous deposit }\end{array}$ & 0 & $\mathrm{~A}$ & $\mathrm{~A}$ & $\mathrm{~A}$ & $\mathrm{~A}$ & & & & + \\
\hline $\begin{array}{l}\text { Textbook of Bacteriol- } \\
\text { ogy, Zinsser, H., and } \\
\text { Bayne-Jones, S., Ap- } \\
\text { pleton-Century Co., } \\
\text { New York, 1934, } 7 \text { th } \\
\text { ed., p. } 310\end{array}$ & Capsulated tetrads & $\begin{array}{l}\text { Transparent at first, } \\
\text { later grayish-white }\end{array}$ & Evenly clouded & 0 & & & & & A & & & + \\
\hline \multirow[t]{3}{*}{ This report } & $\begin{array}{l}\text { White colonies-large } \\
\text { cocci in tetrads or in } \\
\text { groups. No capsule }\end{array}$ & $\begin{array}{l}\text { White, occasionally } \\
\text { with greenish tinge } \\
\text { and halo on blood- } \\
\text { agar }\end{array}$ & $\begin{array}{l}\text { Granular sediment. } \\
\text { Spirals on shaking }\end{array}$ & 0 & $A$ & A & $A$ & $A$ & 0 & + & 0 & 0 \\
\hline & $\begin{array}{l}\text { Yellow colonies-large } \\
\text { cocci, usually all in tet- } \\
\text { rads. No capsule }\end{array}$ & Yellow large & $\begin{array}{l}\text { Granular yellow sed- } \\
\text { iment }\end{array}$ & $\begin{array}{l}+ \text { in } \\
3 \text { wks. }\end{array}$ & 0 & 0 & 0 & 0 & 0 & 0 & 0 & 0 \\
\hline & $\begin{array}{l}\text { Translucent colonies- } \\
\text { cocci pleomorphic, not } \\
\text { in tetrads. No cap- } \\
\text { sule }\end{array}$ & $\begin{array}{l}\text { Smaller, yellow-blue } \\
\text { iridescence }\end{array}$ & $\begin{array}{l}\text { Diffuse with sedi- } \\
\text { ment. Spirals on } \\
\text { shaking }\end{array}$ & $\begin{array}{l}+ \text { in } \\
2 \text { days }\end{array}$ & $A$ & $A$ & $\mathrm{~A}$ & 0 & 0 & 0 & + & 0 \\
\hline
\end{tabular}

lated micrococcus are summarized in the lower portion of Table II.

\section{Variation of the isolated organism}

The striking variations observed in the morphologic characteristics of the cocci and of the colonies at once suggested the operation of dissociative phenomena. On one blood-culture agar-plate the colonies were composed of large and small cocci (Figure 2A). When cocci from this colony were spread on another agar-plate, two types of colony appeared, large porcelain-like cream-colored colonies and a sparse growth of small white colonies (Figure 3B). An agar-plate seeded from a large white colony was permitted to age at room temperature. After 48 hours many of the isolated colonies became sulfur yellow while those crowded together remained smaller and white. After 5 days, opaque yellow "daughter" colonies appeared on some of the large yellow forms. On the twelfth day the colonies were all a golden yellow, and composed of large tetrads. A whitish halo appeared around some of the smaller forms. On the halo, white "daughter" colonies grew and in the yellow center, yellow " daughter" colonies (Figure 3A) developed.

When organisms from the small colony were seeded on agar, small opaque white colonies slowly appeared. The cocci were single, in diploform or in small clusters, pleomorphic and metachromatic (Figure $3 \mathrm{E}$ ). When the plate was examined with a $10 \times$ hand lens after 72 hours, numerous minute transparent colonies less than $0.1 \mathrm{~mm}$. in diameter became visible scattered among the larger (1.5 mm.) whitish ones. Cocci from these colonies were markedly pleomorphic and many were completely decolorized by Gram's method. The cocci varied in size from those as large as the ones illustrated in Figure 3D to ones just within the range of vision of the oil immersion system (Fig- 


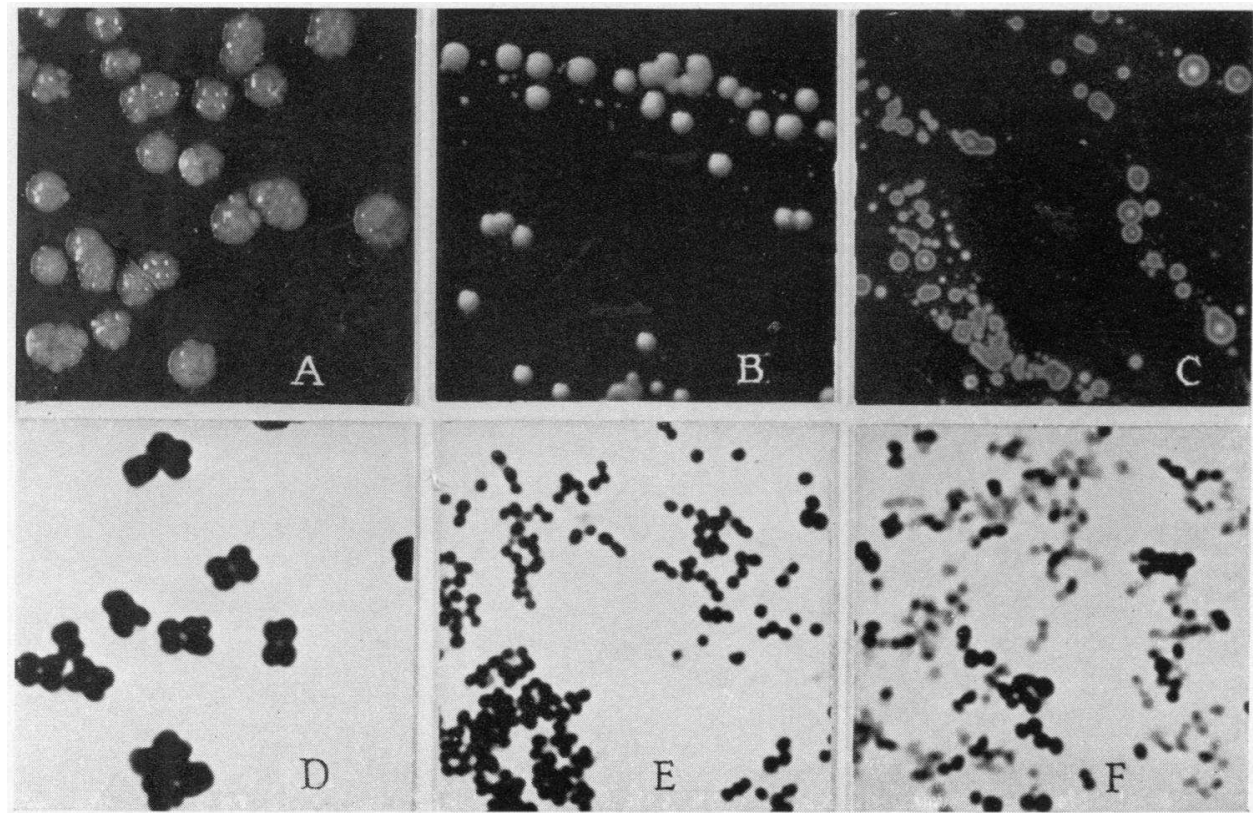

Fig. $3(A)$. Colonies 2 Weeks Old Which Originally Were White Like Those of $B$. After aging they became yellow and later developed a whitish halo-like outgrowth. On the yellow center are yellow "daughter" colonies, on the halo are white "daughter" colonies. (B) Large and Small White Colonies. (C) Large and Small Translucent Colonies. (All slightly magnified.) ( $D$ ) Large Cocci in Tetrads Composing the Yellow Colonies. (E) Small Cocci Single and in Clusters Composing Young White Colonies. (F) Pleomorphic, Metachromatic Cocci Composing the Translucent Colonies.

ure $3 \mathrm{~F})$. After 5 days incubation, the minute colonies increaso to $1 \mathrm{~mm}$. in size and became translucent with a yellow-blue iridescence. Subculture produced colonies which grew more rapily and were translucent. At various times during subsequent subcultures an occasional large white colony or a large yellow one would appear among the myriads of translucent colonies.

Thus from the blood culture at least three distinct, fairly stable forms of colony were obtained, (1) white, (2) yellow and (3) translucent. Other less stable varieties were observed. By special methods to be reported elsewhere, the translucent form was induced to dissociate into a shell-pink variety and an orange-buff variety, each of which bred true on repeated subculture. There was evidence of constant reversion of one form into another. Similar results were observed with the organism isolated from the spinal fluid and knee pus, and with several strains of $M$. tetragenus obtained from culture collections in Vienna and Chicago.

The biological reactions of the organisms com- posing the three varieties of colony varied considerably as shown in Table II. Cocci from the white colonies were large, usually occurred in clusters or tetrads, produced greenish color on blood-agar, did not liquefy gelatin, but fermented dextrose, sucrose, maltose and lactose, and reduced potassium nitrate. Cocci from the yellow colonies were in large and small tetrad formation, were chromogenic, liquefied gelatin slightly after 3 weeks, did not ferment any sugar, or reduce nitrate. Cocci from the translucent colonies were markedly pleomorphic and rarely occurred in tetrads; they liquefied gelatin in 2 days, fermented dextrose, sucrose and maltose but not lactose, did not reduce nitrate and were hemolytic. None of the strains fermented mannite, acidified milk nor formed indol. None were pathogenic for mice. Capsules could never be demonstrated with certainty.

\section{Classification of the organism}

Criteria for the identification of $M$. tetragenus vary considerablv according to different authori- 
ties as a glance at Table II will reveal. No two agree in all respects. In general, the organism is said to occur in large gram-positive, capsulated tetrads in vir'o and to become smaller and lose both capsule and tendency to group in fours on subculture in vitro; the colonies are glisteningwhite; gelatin is not liquefied, milk is not coagulated, blood cells are not hemolized, and no gas is produced in various sugar media. The points of variance are the production of yellow and red pigment (Chauffard and Ramond (1), Sterling (2), Boschi and Bellei (13), LaignelLavastine and Baufle (1), Roger and Trémolières (5), Brugnola $(1,8,20,21,22)$; lack of virulence for animals (Teissier, Boutron (22), Debove, Brugnola, Ziegler, Kramár (1)) ; liquefaction of gelatin (Sterling (15), Jacobelli (22). Chauffard and Ramond, Laignel-Lavastine and Baufle (1)); coagulation of milk (Bergey, Zinsser and BayneJones (15)) ; hemolysis (Leschke (1)) and capsule formation (Bergey (15)).

Practically all of these apparent contradictions can be explained on the basis of microbic dissociation. Much confusion could have been avoided had the early studies of Boschi and Bellei (13) and Jacobelli (22) been more seriously considered. These observers anticipated the modern conception of bacterial variation nearly 40 years ago when they showed that colonies of $M$. tetragenus, aged on agar plates, formed yellow pigment and that after subsequent transfer, while colonies again appeared. Teissier (22) in 1896 even noted the formation of "daughter" colonies. For a time it was controversial as to whether many different strains existed or if the different forms were all variants of a single strain. It seems now that both views were correct; numerous strains exist and each may dissociate into various forms.

There has been considerable difficulty in differentiating $M$. tetragenus from the staphyloccus to which it is closely related. The differences between typical undissociated strains of either type are distinct. The dissociated forms of one may, however, resemble either the undissociated form of the other or its variants so closely that identification is almost impossible, except if reversions to the original form occur. For example, Hoffstadt and Youmans (23) have dissociated the Staphylococcus aureus into a number of variant forms, some of which were no longer chromogenic, no longer liquefied gelatin and no longer caused hemolysis. These are reactions also characteristic of $M$. tetragenus. On the other hand, as I have shown, one of the dissociated forms of $M$. tetragenus liquefied gelatin, caused hemolysis and its cocci grew in clusters and produced colonies with a blue-yellow iridescence; it was thus indistinguishable from the staphylococcus except that milk was not acidified and that occasional reversions to the original form occurred.

\section{COMMENT}

Increased knowledge of microbic dissociation has explained many of the older difficulties in the classification of bacteria. When comparing one species of organisms with another it is necessary to deal with known variants of each. As shown in this study, the "typical" undissociated forms of $M$. tetragenus and $S$. aureus are distinct. whereas the dissociated forms of one may be indistinguishable from those of the other. Similar phenomena have been encountered in the study of other bacteria. The relation of microbic dissociation to infection, disease and recovery is but little understood. It is of interest to speculate as to the form or phase or cyclostage in which $M$. tetragenus existed in the patient described in view of the fact that the organism was seen in its "atypical " (?) form in the pus from the knee and spinal fluid and because of its slow growth on first subculture and its presence in the spinal fluid after the patient had apparently recovered. Further studies in this regard and a detailed description of the five variant forms will be presented elsewhere.

The isolation of a bacterium which grew in colonies of different character each composed of cocci of different size, shape, arrangement and biologic reactions from the same patient would lead one to suspect a mixed infection or contamination. It became evident that a single species with its variant forms was concerned after the transformation of one form of colony into another on culture media had been watched. It is possible that cases of $M$. tetragenus infection are occasionally missed because of the variability of the isolated organism, or without further study cases are easily mistaken for staphylococcus infection. 


\section{SUMMARY}

A nonfatal case of $M$. tetragenus infection with septicemia, purulent arthritis and meningitis is described. The organisms isolated from the patient's blood, pus from the knee and from the spinal fluid conformed in general to the criteria established for the species Gaffkya tetragena. From the typical white colonies isolated, two variant forms developed, one yellow, the other translucent; each form of colony was composed of cocci of different but constant characteristics. Reversion or transformation of one form into another on culture media was observed. The biologic characteristics of the variant forms vary considerably, which helps to explain the apparently contradictory criteria of numerous authorities regarding the differentiation of $M$. tetragenus from staphylococci.

\section{BIBLIOGRAPHY}

1. Reference given in Table I.

2. Cited by von Ofenheim (1).

3. Cited by Luigi (1).

4. Viquerat, Der Micrococcus tetragenus als Eiterungserreger beim Menschen. Ztschr. f. Hyg., 1894, $18,411$.

5. Birks, A. H., Thornley, R. T., and Fawcus, R. A., Septicaemia due to micrococcus tetragenus as a cause of pyrexia at the front. Quart. J. Med., 1916, 10, 1.

Trémolières, F., and Loew, P., La Tétragénémie Epidémique. Paris méd., (Part Méd.), 1915, 17, 94 and 167.

6. I am indebted to Dr. J. P. Spano for translation of the Italian articles.

7. Cited by Leschke (1).

8. Achard, C., and Gaillard, L., Contribution a l'étude biochimique des genres Tétragène et Staphylo- coque. Arch. d. Méd. Exper. et d'Anat. Path., 1899, 11, 96.

9. Gayet, Septicémie à tétragène pur chez urinaire. J. d'urol., 1927, 24, 72.

10. Ceraulo, S., and Vetrano, G., Ueber eine Form von Mischseptikämie (Micrococcus melitensis und Tetragenus). Ztschr. f. klin. Med., 1910, 70, 319.

11. Oettinger, $\mathrm{A}$ propos des septicémies à tetragènes. Semana méd., 1906, 26, 68.

Roger and Trémolières, Septicémie à tetragènes Semana méd., 1906, 26, 55.

12. Cited by Bonanno (1).

13. Cited by Müller (19).

14. Kimmerle, A., Zwei Fälle von Tetragenusinfektion, ein Beitrag zu der Frage der Tetragenusinfektion. Fortschr. d. Med., 1930, 48, 305.

15. Reference given in Table II.

16. Cited by Lambea (20).

17. Cited by Kimmerle (14).

18. Cathala, V., and Guéniot, P., Valeur de l'ensemencement du Sang. l'Obstetrique, 1910, 3, 433.

19. Müller, R., Ueber abdominelle Infektionen mit Mikrococcus tetragenus. Wien. Klin. Wchnschr., 1904, 17, 815.

20. Lambea, J. V., Estudios Clínicos y experiencias sobre el micrococcus tetragenus. Progresos de la clín., $1927,37,352$.

21. Vincenzi, L., $\mathrm{Di}$ un nuovo tetrageno patogeno. Riforma med., 1897, 13, 758.

22. Jacobelli, F., Richerche sulla Morfologia e Biologia del Considetto Gruppo dei Tetrageni. Riforma med., 1899, 15, 122 and 135.

Teissier, $P$. , Contribution a l'Étude du Tétragène. Arch. d. méd. Exper. d'Anat. Path., 1896, 8, 14.

Boutron, A. F. A., Recherches sur le Micrococcus tétragènus septicus et quelques espèces voisines. Centralbl. f. Bakt., Ref., 1894, 16, 971.

23. Hoffstadt, R. E., and Youmans, G. P., Staphylococcus aureus. Dissociation and its relation to infection and to immunity. J. Infect. Dis., 1932, 51, 216.

24. For a review of older literature see Stubenrath, F. C., Das Genus Sarcina, Munich, 1897. 